\title{
ВИКОРИСТАННЯ МЕТОДІВ МАТЕМАТИЧНОГО МОДЕЛЮВАННЯ ДЛЯ ПІДВИЩЕННЯ ЕФЕКТИВНОСТІ ЕКСТРАКОРПОРАЛЬНОГО ЗАПЛІДНЕННЯ. ПОСТАНОВКА ПРОБЛЕМИ
}

\author{
О. П. Мінцер, С. В. Денисенко ${ }^{1}$ Ю. М. Лесняк \\ Національна медична академія післядипломної освіти імені П. Л. Шупика \\ Клініка проблем планування сім'ї'
}

Представлена класифікація методів математичного моделювання, що використовуються для підвищення ефективності екстракорпорального запліднення. Проаналізовані результати застосування подібних моделей.

Ключові слова: метод екстракорпорального запліднення, математичне моделювання, багатофакторні моделі, результативність екстракорпорального запліднення, імітаційне моделювання, репродуктивна технологія.

\section{ИСПОЛЬЗОВАНИЕ МЕТОДОВ МАТЕМАТИЧЕСКОГО МОДЕЛИРОВАНИЯ ДЛЯ ПОВЫШЕНИЯ ЭФФЕКТИВНОСТИ ЭКСТРАКОРПОРАЛЬНОГО ОПЛОДОТВОРЕНИЯ. ПОСТАНОВКА ПРОБЛЕМЫ}

\author{
О. П. Минцер, С. В. Денисенко ${ }^{1}$, Ю. Н. Лесняк \\ Национальная медицинская академия имени П.Л. Шупика МЗ Украины \\ ${ }^{1}$ Клиника проблем планирования семьи
}

\begin{abstract}
Представлена классификация методов математического моделирования, используемых для повышения эффективности экстракорпорального оплодотворения. Проанализированы результаты использования подобных моделей.
\end{abstract}

Ключевые слова: метод экстракорпорального оплодотворения, математическое моделирование, многофакторные модели, результативность экстракорпорального оплодотворения, имитационное моделирование, репродуктивная технология.

\section{USE OF METHODS OF MATHEMATICAL DESIGN FOR INCREASE OF EFFICIENCY OF EXTRACORPORAL FERTILIZATION. RAISING OF PROBLEM}

\author{
O. P. Mintser, S. V. Denysenko', Yu. M. Lesnyak
}

National Medical Academy of Post-Graduate Education named after P. L. Shupyk

${ }^{1}$ The Human Reproduction Problems Clinic

There were presented the results of patterning a mathematical multifactor model of efficiency of the method of extracorporal fertilization.

Key words: method of extracorporal fertilization, mathematical design, mathematical multifactor models, effectiveness of extracorporal fertilization, imitation design, reproductive technology.

Вступ. Демографічна ситуація в ряді країн сьогодні оцінюється як критична, що обумовлено знач ним зниженням народжуваності та зростанням смертності $[2,4]$. Дані епідеміологічних досліджень свідчать, що частота безпліддя серед подружніх пар дітородного віку коливається від $8 \%$ до $15 \%$, й у ряді регіонів має тенденцію до збільшення [5].
Використання сучасних допоміжних репродуктивних технологій (ДРТ) дозволяє відновити репродуктивну функцію у більшості хворих. Цьому сприяють наукові досягнення останніх десятиліть: розшифровка механізмів ендокринного контролю менструального циклу, синтез і клінічне застосування гормональних препаратів, використання ендоскопічних методів 
діагностики та лікування, розроблення та впровадження в клінічну практику різних методів екстракорпорального запліднення (ЕКЗ). До теперішнього часу по всьому світу народжений понад мільйон дітей із застосуванням різних методів ДРТ.

Незважаючи на зовнішню простоту виконання цього методу частота настання вагітності при ЕКЗ не перевищує 35-39 \% [3]. Останнім часом виконано немало робіт із вдосконалення протоколів стимуляції овуляції у жінок у програмах допоміжних репродуктивних технологій, пропонуються різні варіанти їх застосування залежно від початкового стану здоров'я пацієнток $[3,5,9,10]$. Активно з'ясовуються можливості оптимізації лікувально-діагностичних заходів на етапі підготовки до ДРТ $[8,11,12]$. Підготовка пацієнток до програми займає іноді тривалий час, оскільки необхідно виконати всі діагностичні маніпуляції, виключити запальні захворювання органів малого таза, скоректувати різні гормональні порушення тощо.

Зрозумілим бажанням стає застосування методів математичного моделювання для істотного підвищення ефективності ЕКЗ. Зокрема, корисним здається аналіз дії окремих чинників на результативність ЕКЗ $[3,6]$. Проте, строго кажучи, серйозного використання математичного моделювання не проводилося.

Слід зауважити, що на цьому етапі розвитку медицини математичне моделювання активно застосовується в різних напрямах як для виявлення існуючих взаємозв'язків чинників з ознакою, що цікавить дослідника, на основі спеціальних математичних методів $[1,7]$, так і системного моделювання патологічних процесів. Проте, для практичного застосування в репродуктивній медицині систематизація математико-біологічного матеріалу абсолютно необхідна.

Метою роботи стало визначення класифікації методів математичного моделювання, що можуть бути застосовані для підвищення ефективності екстракорпорального запліднення.

Підкреслимо, що методи математичного моделювання для будь-якої проблеми, в тому числі і для ЕКЗ, можна систематизувати та класифікувати, передусім, за тими природничонауковими завданнями, для яких вони призначені.

Матеріали та методи досліджень. Всі методи математичного моделювання для програм ЕКЗ можна умовно поділити на три групи. До першої слід віднести дослідження результативності екстракорпорального запліднення і визначення варіантів підвищення його ефективності на основі формальних прийомів статистичного аналізу, зокрема багатофакторного кореляційного аналізу для виділення груп чинників, переваж- но тих, що впливають на результативність процесу. Побудова на цій основі відповідної математичної багатофакторної моделі, безперечно, дозволить визначити оптимальні варіанти проведення, а також дасть можливість прогнозувати результати ЕКЗ.

У літературі є досить велика кількість досліджень застосування багатофакторного кореляційного аналізу для виділення групи чинників, процедур ознаки, що істотним чином впливають на результативність i побудову математичної багатофакторної моделі. Також очевидним є використання прогностичних моделей, вибору на подібній основі максимально позитивного варіанту методики ЕКЗ.

Так, застосування багатофакторного кореляційного аналізу для виділення груп чинників проводилося групою авторів (Самойлова А.У. з співавт., 2011) в роботі [8]). Математичне моделювання здійснювалося за даними 266 пацієнток, що пройшли амбулаторне обстеження. Всім їм було виконано ЕКЗ. 1-у групу склали 146 пацієнток, 2-у - 120 відповідно 3 негативними і позитивними результатами. Клінічний стан оцінювався за 45 параметрами.

На основі багатофакторного кореляційного аналізу, за значеннями коефіцієнтів приватної кореляції на першому етапі були виділені дві групи чинників: перша зі значеннями приватної кореляції до 0,3 включно, друга - вище. Межа ділення чинників на дві групи (значення 0,3 ) визначалася на основі ряду критеріїв, одним з яких є оптимальність кількості чинників з максимальним позитивним результатом їх дії на досліджувану ознаку. До математичного моделювання відмінності між групами були виявлені за такими чинниками: вік жінки, кратність спроб, тривалість спостереження з приводу безпліддя, наявність ендометриту й ендоцервіциту, виявлений хламідіоз, наявність кісти та резекція яєчника в анамнезі; за рівнем інгібіну; антитіл до бетаХГЧ; АМГФ. На основі аналізу чинників другої групи, за приватними коефіцієнтами множинної кореляції та порівняння показників якості варіантів багатофакторних моделей було віддано перевагу варіанту математичної багатофакторної моделі, що включала 16 факторів.

Запропонована авторами багатофакторна модель мала високий коефіцієнт множинної кореляції, рівний 0,97, і коефіцієнт множинної детермінації, рівний 0,96 . На якість моделі впливав не лише кількісний склад чинників (варіанти моделей 37 чинників мали коефіцієнт множинної детермінації, що не перевищує значення 0,62), але і структурний (модель, що містить інший набір 16 чинників, мала істотно менший коефіцієнт множинної детермінації - 0,87). 
Як показують результати рішення першої задачі, істотно збільшений (до 16) в порівнянні з відомим у літературі $[3,4,5]$ перелік чинників, що підлягають дослідженню на предмет включення їх в основу не лише нових методик, але і їх різних комбінацій. Слід зауважити, що визначальним у формуванні цієї групи став коефіцієнт множинної детермінації R2. Приватні коефіцієнти кореляції багатофакторної моделі дають якісну картину взаємозв'язків чинників з ознакою і в сукупності з аналізом самого чинника визначають напрями досліджень у наступних перелічених вище завданнях. Отримана модель дозволяє звернути увагу клініцистів на найбільш значимі критерії в досягненні позитивного результату при лікуванні безпліддя методом ЕКЗ.

Друга група методів математичного моделювання пов'язана з застосуванням математичних моделей в області гормональної регуляції репродуктивної функції жінок. Зрозуміло, розвиток методів цієї групи стимулюється необхідністю пояснення процесів, дослідження яких прямими методами обмежене через складність явищ, що вивчаються, а також морально-етичні міркування. Крім того, забезпечення можливості і необхідності розроблення методів оптимізації процедури індукції суперовуляції повинно здійснюватися з урахуванням індивідуальних характеристик жінок.

Використання екзогенних гормональних препаратів при стимуляції яєчників призводить до порушення природних гомеостатичних механізмів регуляції росту та дозрівання фолікулів, тому завдання управління системою гіпофіз - яєчники в циклах ЕКЗ цілком покладається на лікаря, і результат стимуляції багато в чому залежить від вибору тактики ії ведення.

Всі рішення про корекцію виду і дози індукторів суперовуляції, часу введення тих або інших гормональних препаратів, а також їх відмінення та припинення спроби ЕКЗ у цьому менструальному циклі приймаються після оцінювання динаміки відповіді яєчників на підставі даних ультразвукового та гормонального моніторингу, отриманих у процесі стимуляції. Вважається, що динаміка рівня сироваткового естрадіолу (Е2) найкраще відображає як міру зрілості преовуляторних фолікулів, так і адекватність індукції суперовуляції [1 ].

Проте частота проведення гормональних досліджень обмежена їх високою вартістю. Використання ж одного ультразвукового моніторингу для оцінювання відповіді яєчників на стимуляцію є недостатньо інформативним [10]. Крім того, в літературі немає єдності поглядів відносно чітких критеріїв, якими можна було б керуватися при інтерпретації результатів моніторингу $[1,6,7,10]$.
Результати та їх обговорення. В ситуаціях, коли інформація, отримана про фізіологічні процеси за допомогою прямих методів, неповна, а окремі характеристики важкодоступні для виміру, видається перспективним використання непрямих методів оцінювання станів досліджуваної системи, до яких, зокрема, належить математичне моделювання. Цей метод передбачає заміну досліджень реального об'єкта дослідженнями його математичної моделі, що є рівнянням або системою рівнянь, взаємозв'язку основних змінних, що характеризують реальний фізіологічний процес або описувану систему. Модель, що адекватно описує процеси, котрі відбуваються в реальній системі, дозволяє досліджувати можливі відповіді системи на зовнішні дії (наприклад, введення гормональних препаратів, лікарських речовин тощо) і може бути використана для аналізу й інтерпретації результатів клінічних досліджень, ухвалення оптимального рішення про управління реальною системою.

Завдання, які повинен вирішувати лікар на етапі індукції суперовуляції, зводяться до можливості їх оптимізації за допомогою методів математичного моделювання. Важливими моментами індукції суперовуляції є визначення типу реагування пацієнтки на стимуляцію та прогнозування результату ЕКЗ.

Застосування індукції суперовуляції у клінічно здорових жінок з нормальним менструальним циклом виявило різні типи реакцій яєчників на стимуляцію [10, 15]. На підставі показників рівня Е2 в процесі індукції суперовуляції виділяють три види реагування - нормальний (концентрація сироваткового Е2 до моменту введення ХГ складає 900-2000 пг/мл), слабкий (нижче 900 пг/мл) і надмірний (понад 2000 пг/мл)[1]. Групи пацієнток із слабким і надмірним типами реагування є прогностично несприятливими відносно настання вагітності. В першому випадку існує високий ризик розвитку синдрому гіперстимуляції яєчників, в другому - відповідь яєчників характеризується як "погана" і вимагає припинення процедури [1]. В обох випадках для досягнення успішного результату ЕКЗ потрібен підбір індивідуальної схеми стимуляції [10].

Питання про вибір схеми індукції суперовуляції вирішується до початку лікування, проте ii "налаштування" на конкретну пацієнтку здійснюється безпосередньо в процесі стимуляції, i, в основному, базується на особистому досвіді фахівців.

Цінність адекватної математичної моделі полягає в тому, що іiї параметри можна настроїти так, щоб вона відтворювала дані лабораторних і інструментальних досліджень конкретної жінки. Така процедура також є непрямим методом оцінювання пара- 
метрів функціонального стану фізіологічних систем. Сподіватимемося, що за допомогою індивідуальної моделі функціонального стану системи гіпофіз - яєчники підбір режиму стимуляції для конкретної жінки і відповідно попередній прогноз результату ЕКЗ можливо буде здійснювати до початку лікування.

Підкреслимо, що, дотримуючись принципу повноти (при побудові математичної моделі реального процесу не повинна виникати невизначеність, тобто для кожної ситуації повинно бути ясно, що в ній станеться) важливо, щоб для кожної компоненти системи, що вивчається, була визначена ії роль і поведінка в цій ситуації. При цьому можливе використання відомостей ймовірнісного характеру. Тільки при дотриманні умов повноти можна досліджувати функціонування системи і стежити за тим, як змінюється іiі структура з часом. Вимога повноти опису процесу відноситься в першу чергу до емпіричного вивчення цього процесу. Якщо ця вимога не дотримується, тобто якщо одні компоненти даного процесу вивчаються детально, а інші випускаються з уваги, то побудова замкнутої математичної моделі процесу може виявитися неможливою через нестачу змістовних відомостей.

Так, в моделі менструального циклу у жінок, запропонованій Н. Thompson і співавт. [14], модель Lamport була доповнена пропозицією визначити швидкість секреції Е2 пропорційною не концентрації ФСГ, а розміру зростаючого фолікула. ФСГ, у свою чергу, управляє ростом фолікула (швидкість росту фолікула пропорційна концентрації ФСГ). Досягши заздалегідь заданого розміру, фолікул овулює (у моделі його розмір миттєво знижується до нуля), і фолікулярна фаза завершується різким спадом естрогену. Отже, саме ріст, а потім овуляція фолікула, який продукує Е2, передбачається визначальним чинником у виникненні періодичності системи.

Модель складається 3 трьох диференціальних рівнянь, два 3 них, як і в моделі Lamport, описують матеріальний баланс естрогену і ФСГ в плазмі крові, а третє - ріст і овуляцію естрадіолосекретуючого фолікула. За допомогою цієї моделі авторам вдалося формально відтворити періодичні незгасаючі коливання сироваткових концентрацій гормонів (ФСГ і Е2) впродовж менструального циклу, що генеруються в моделі навіть при постійній концентрації ФСГ у крові (за відсутності негативного зворотного зв'язку). Проте, в моделі не враховується вплив ЛГ на фолікулогенез, не розглядається зростання інших гонадотропінзалежних фолікулів когорти, здатних піддаватися атрезії і тих, що беруть участь у формуванні сиро- ваткового Е2 і регуляції секреції ФСГ до моменту селекції домінантного фолікула, тому використання іiї в практичних цілях вимагає включення додаткових припущень. Крім того, в моделі постулюються погано з'ясовані з фізіологічної точки зору процеси. Так, інгібірування секреції ФСГ естрогеном моделюється формально за допомогою процесу виведення ФСГ 3 крові, швидкість якого пропорційна концентрації естрогену, що свідомо - невірно, оскільки такий процес відбуватиметься в моделі навіть за відсутності в крові ФСГ. У рівнянні, що визначає ріст фолікула, не враховуються проліферація і загибель клітин гранульози.

I лише в роботах С. П. Олімпієвої та співавт. була створена модель, в якій вказані вище суперечності були усунені $[3,4,8]$. Модель використовувалася при створенні комп'ютерної консультативної системи для здійснення інтелектуальної підтримки інтерпретації результатів гормональних вимірів при діагностиці ендокринно обумовлених порушень жіночої репродуктивної функції. Показано, що модель відтворює багато патологічних станів, що спостерігаються в клініці, в системі гіпофіз - яєчники, зокрема таких, як дисгенезія гонад, гіперпролактинемія, гіпогонадотропний гіпогонадизм, збільшення тривалості фолікулярної фази циклу на тлі збільшення маси жирової тканини і тому подібне. За допомогою моделі вдалося встановити відповідність між картиною залежності від часу концентрацій Е2, ФСГ і розміру домінантного фолікула, з одного боку, виду порушень в системі гіпофіз - яєчники і можливими екстраоваріальними причинами цих порушень, з іншого.

Отже, емпіричне вивчення природних процесів часто виявляється клаптиковим, а це сильно лімітує можливості застосування математичного моделювання в проблемі, що вивчається.

Очевидно, значне місце в математичному моделюванні повинні займати різні " передмоделі", тобто побудова логічних схем майбутніх моделей, що повинні їм передувати. Призначення таких "передмоделей" полягає в тому, щоб в умовах нестачі інформації для побудови моделі в цілому по можливості зв'язати воєдино наявні уявлення про перебіг явища і з'ясувати, які додаткові дослідження слід провести для отримання необхідних даних при побудові повної моделі. При цьому слід зважати на вимоги принципу повноти. Приймається, що у цілому ряді випадків складні процеси життєдіяльності організовані ієрархічно. Це означає, що є ряд взаємодіючих, але відносно автономних простіших процесів, причому ті або інші особливості перебігу одних процесів істотним чином змінюють перебіг інших процесів. Отже, всю 
сукупність цих процесів до певної міри можна впорядкувати таким чином, що один процес вважатиметься підлеглим іншому.

Розглядаючи математичну природу оптимізаційних завдань стосовно проблем репродуктивних технологій, відмітимо, що основне завдання полягає в обгрунтуванні можливості вибору того або іншого варіанту перебігу процесу. При цьому повинно бути твердо відомо, що можна варіювати. 3 іншого боку, має бути визначений деякий критерій, що дозволяє порівняти між собою різні можливі варіанти перебігу процесу. В буквальній постановці завдання оптимізації полягає в тому, щоб з'ясувати, чи існує варіант перебігу процесу, при якому вибраний критерій набуває обгрунтованого значення, і якщо такий варіант існує, то забезпечити його реалізацію.

Природно виникає питання про єдиність оптимального процесу і про знаходження ефективних способів його побудови. У випадку, якщо оптимального процесу в строгому сенсі не існує, нерідко доводиться обмежуватися таким варіантом перебігу процесу, при якому критерій набуває досить сприятливого значення.

Можна стверджувати, що в процесах репродукції здійснюється оптимізація заданих функціоналів (принцип мінімізації зусиль із досягнення заданого результату, мінімізація генетичної аберації тощо). Абсолютно ясно, що такі підходи мають сенс, якщо йдеться про керовані процеси. У цих випадках саме дослідник формулює критерій якості, відповідно до якого він управляє природним процесом, а звідси природним чином визначається той функціонал, в оптимізації якого він зацікавлений.

У той же час при подібному підході існує ризик недостатнього біологічного обгрунтування можливих результатів, якщо невідомі відповідні закони. Зрозу-

\footnotetext{
Лiтература

1. Аншина М. Б. Принципы гормонального мониторинга в программе ЭКО / Аншина М. Б. // Проблемы репродуктологии. - 1995. - № 2. - С. 43-48.

2. Киликовский В. В. Экспертная консультативно-диагностическая система по эндокринным нарушениям репродуктивной функции женщины (РЕПРОКОД) / Киликовский В. В., Олимпиева С. П., Задорожная И. К. // Информационные системы поддержки медицинского страхования: респ. сб. науч. тр. под ред. проф. С. А. Гаспаряна. - М., 1994. - С. 154-162.

3. О критериях назначения хорионического гонадотропина при контролируемой индукции суперовуляции / Корсак В. С., Исакова Э. В., Каменецкий Б. А. [и др.] // Проблемы репродуктологии. - 1998. - № 3. - С. 50-54.
}

міло, що відсутні і гарантії того, що процес, котрий перебігає сам по собі, забезпечить оптимізацію запропонованого функціоналу. Оскільки в завданні зазвичай використовується деяка кількість невідомих параметрів, сенс яких залишається неясним, то після аналітичного вирішення задачі і вдалого підбору значення цих параметрів, цього далеко не досить для підтвердження загальної теорії.

Для практичних застосувань найбільш важливим класом є клас портретних моделей, побудованих при значеннях параметрів, близьких до реальних.

За своєю суттю ці моделі є феноменологічними. Згідно з термінологією сучасного системного аналізу, їх можна вважати імітаційними моделями процесів, що перебігають у реальних співтовариствах. Проте, вони незручні для аналітичного дослідження. Тому доцільно створювати спрощені моделі пошукового типу для простих ситуацій з подальшим їх використанням для побудови складних моделей портретного типу.

Висновки. 1. Запропонована систематизація методів математичного моделювання для підвищення ефективності методів екстракорпорального запліднення. 2. Виділені п'ять груп математичних підходів: 1) використання багатофакторного аналізу для виділення тих чинників, що істотним чином впливають на результативність процесу; 2) визначення оптимальних варіантів проведення ЕКЗ на основі комплексного (системного) аналізу для отримання максимально можливого позитивного результату; 3) математичне прогнозування результатів ЕК3; 4) побудова імітаційних моделей; 5) використання математичних моделей структурного типу в галузі гормональної регуляції репродуктивної функції жінок; 6) використання портретних моделей процедур ЕКЗ.

4. Леонов Б. В. Состояние проблемы экстракорпорального оплодотворения и переноса эмбрионов (ЭКО и ПЭ) в России / Б. В. Леонов, В. И. Кулаков // Акушерство и гинекология. - 1998. - № 1. - С. 4-5.

5. Никитин А. И. Факторы неудач в программах вспомогательной репродукции / Никитин А. И. // Проблемы репродуктологии. - 1995. - № 2. - С. 36-42.

6. Система интеллектуальной поддержки интерпретации результатов гормональных измерений при нарушениях женской репродуктивной функции / Олимпиева С. П., Киликовский В. В., Задорожная И. К. [и др.] // Стратегия здоровья: интеллектуальное обеспечение медицины : труды III Международного форума, 14-20 мая, г. Гурзуф, 1994. C. $70-71$. 
7. Попов Г. Д. Некоторые аспекты неразвивающейся беременности после ЭКО / Попов Г. Д., Кузнецов С. Л., Старостина Т. А. // Современные подходы к лечению бесплодия : сб. научн. тр. - Екатеринбург, 2002. - С. 142-143.

8. Математическое моделирование в исследовании результативности экстракорпорального оплодотворения / Самойлова А. В., Орлов В. Н., Гунин А. Г., Милаев С. Г. // Казанский медицинский журнал. - 2009. - № 6. - С. 889-892.

9. Gougeon A. Regulation of ovarian follicular development in primates: facts and hypotheses / A. Gougeon Endocrin. Rev. 1996. - Vol. 17. - P. 121-155.

10. J. F. Kerin Monitoring of ovarian response to stimulation in vitro fertilisation cycles / J. F. Kerin, G. M. Warnes // Clin. Obstet. Gynecol. - 1986. - Vol. 29. - P. 158-206.

11. Lamport H. Periodic changes in blood estrogen / H. Lamport Endocrinol. - 1940. Vol. 27. - P. 673-679.

12. A theory of follicular selection: II. Computer simulation of estraiol administration in the primate/H. M. Lacker, W. H. Beers, L. E. Meuli [et. al.] Biol. Reprod. - 1987. - Vol. 37. - P. 581-588.
13. Meuli L. E. Experimental evidence supporting a mathematical theory of the physiological mechanism regulating follicle development and ovulation number / L. E. Meuli, H. M. Lacker, R. B. // Thau Biol. Reprod. - 1987. - Vol. 37. - P. 589-594.

14. Thompson H. E. A simplified mathematical model and simulations of the hypophysis-ovarian endocrine control system / H. E. Thompson, J. D. Horgan, E. Delfs // Biophys. J. 1969. - Vol. 9. - P. 27.

15. Is your IVF programme good? / M. Alper, P. Brinsden, R. Fischer [et al.] // Human Reproduction. - 2002. - Vol. 17, № 1 - P. 8-10.

16. Delvigne A. Epidemiology and prevention of ovarian hyperstimulation syndrome (OHSS): a review / A. Delvigne S. Rosenberg// Hum. Reprod. Update. - 2002. - Vol. 8, № 6. P. 559-577.

17. Is hydrosalpinx fluid cytotoxic / I. Granot, N. Dekel, I. Segal [et al.] // Hum. Reprod. - 1998. - Vol. 13, № 6. - P. 1620-1624. 